\title{
THE EFFECTS OF INORGANIC. AND ORGANIC PHOSPHATE COMPOUNDS ON NERVOUS ACTIVITIES
}

\author{
YUTAKA OOMURA AND SABURÔ HASHIMURA* \\ Department of Physiology, Faculty of Medicine, Kyushu University, Fukuoka
}

Since adenylpyrophosphate (ATP) was discovered by Embden and Zimmermann ('27) and phosphate creatine (CrP) by Eggleton and Eggleton ('27) and by Fiske and Subbarow ('29) indépendently, each step in the metabolism has become clear.

Moreover the conception of the presence of "energy-rich phosphate bonds" (Lipmann, "46) in living tissues brought out the importance of ATP and CrP as energy sources of the action of living tissues, especially in regard to muscle contraction.

Recent experimental results have suggested that nervous activity may depend on the relation between energy-rich phosphate compounds and electrolytes, as to some extent in the case of muscle contraction (Minz, '47, Nachmansohn, '46) and that the development of the membrane potential of a resting nerve and the subliminal and threshold responses of a nerve may be associated with pyruvate metabolism (Lorente de Nó. '47, Shanes, '42, '44, '46).

The present work was undertaken with the hope that some information might be gained regarding the relationship of phosphate to nervous activity, especially, the rôle played by the inorganic and energy-rich phosphate compounds in the active and resting states of nerves.

METHODS

A single motor fiber (diameter: 10 to $15 \mu$ ) of the nerve innervating the gastrocnemius, sartorius or semitendinosus muscle of the Bufo vulgaris japonica was dissected out under a binocular microscope and mounted on two separate glass plates, filled with Ringer's solution ("bridge-insulator" Tasaki, "39). In the gap (ca. $0.5 \mathrm{~mm}$.) between the glass plates, the internodal stretch of the fiber was mounted, and in the pools of Ringer's fluid were dipped non-polarizable electrodes of $\mathrm{Zn}-\mathrm{ZnSO}_{4}$-Ringer (agar) type, connected to the stimulating and recording circuit.

After measuring the normal threshold value, the accommodation constant $\lambda$ (Hill, '36), the excitatory state, and the resting potential, further measurements were made replacing Ringer's fluid in one pool (generally the central pool) with the test solution. The details of these measurements are as follows:

Received for publication August 20, 1952.

* 大村 裕, 橋村三郎 


\section{The measurement of the threshold}

The excitation of nerve was evoked by a brief condenser discharging current and the threshold determination was made by observing the action currents of the nerve fiber with the cathode-ray oscillograph. For this purpose a condenser $(0.02 \mu \mathrm{F})$ was discharged through a fixed resistance $(4 \mathrm{k} \Omega)$ and a variable resistance $(r)$ opening the contact key $(K)$ of a Helmholz type pendulum. The stimulating circuit is presented diagrammatically in figure 1 . The threshold of each node dipped in pools was measured alternately by changing the direction of the applied voltage ( $A$ in fig. 1 ).

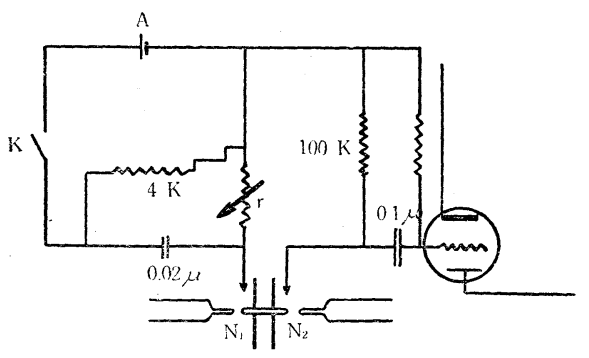

FIG. 1. Arrangement for applying a condenser discharging current and for recording the action current of a single motor nerve fiber. An isolated single nerve fiber is used for leading off the action current from the site of stimulation. $K$ is a contact key of the Helmholtz type pendulum. The stimulating voltage of each Ranvier's node is given by changing the direction of the applied voltage (A).

\section{The measurement of the accommodation curve}

The accommodation constant of the nerve fiber was measured by applying exponentially increasing voltages with various time constants, the action current of the nerve fiber being taken as the index of the excitation (in accordance with Tasaki's ('49, '50) and Sato's ('51) reports).

\section{The measurement of the excitatory state (E-state)}

The method and apparatus for measurement were the same as those in Tasaki's report ('49). For the conditioning stimulus was adopted a constant current, the intensity of which was $40 \%$ of the rheobase. The test shock was produced by the condenser discharging current.

\section{Measurement of the resting potential of the nerve fiber}

The resting potential was measured with a modified surface-potential measuring circuit by the vibrating capacity method (the sensitivity was $\pm 0.3 \mathrm{mV}$ ) (Sato and Koga, '52) (fig. 2, $A$ ).

FIG. $2(A)$. The resting potential was measured with the circuit shown in diagram, $P$ is a Leeds and Northrop potentiometer and $C$ consists of two copper disks, one of which vibrates with a frequency of 150 cycles/sec. The Braun tube is used as zero indicator.

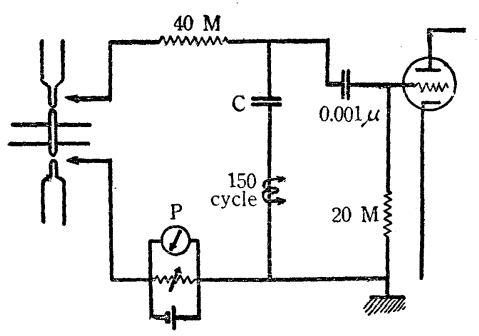

By changing the circuit connected to the input of the amplifier, the threshold and the resting potential were alternately measurable. 
We used an inorganic phosphate solution of the following composition $\begin{array}{llll}\mathrm{Na}_{2} \mathrm{HPO}_{4} & 56.0 \mathrm{mM} & p_{\mathrm{H}} & 7.6\end{array}$

..... $\mathrm{KCl}$ Increasing of osmotic pressure : 5.45 A.P.

$\mathrm{CaCl}_{2} \quad 1.8 \mathrm{~mm}$

$\mathrm{NaHCO}_{3} \quad 2.3 \mathrm{~mm}$

and Ringer's solution

$\begin{array}{llll}\mathrm{NaCl} & 110.0 \mathrm{mM} & p_{\mathrm{H}} & 7.3\end{array}$

$\mathrm{KCl} \quad 2.7 \mathrm{~mm} \quad$ Increasing of osmotic pressure : 5.27 A.P.

$\mathrm{CaCl}_{2} \quad 1.8 \mathrm{~mm}$

$\mathrm{NaHCO}_{3} \quad 2.3 \mathrm{~mm}$

$\mathrm{CrP}$ was extracted as Ca-salt from the gastrocnemius muscle of the cat at $0^{\circ} \mathrm{C}$., according to the method of Fiske and Subbarow ("29).

ATP also was extracted as Ba-salt from the similar muscle of the rabbit under the same conditions, according to Kerr ('41).

CrP Ca-salt or ATP Ba-salt was dissolved in Ringer's solution.

RESULTS

\section{The Effect of Inorganic Phosphate}

a) Resting potential. Within a few seconds after replacing the Ringer's solution in the central pool $\left(N_{1}\right)$ with $0.056 \mathrm{M} \mathrm{Na}_{2} \mathrm{HPO}_{4}$-Ringer's solution, a negative resting potential was produced at this node and this potential continued to elevate gradually for about 30 minutes. The maximum potential was about $5 \mathrm{mV}$. Only a small change of the potential was noticed after the maximum value was reached (fig. $2, B$ ).

FIG. $2(B)$. A series of measurements of the resting potential and the threshold during a certain period after the application of the inorganic phosphate-Ringer's solution to one Ranvier's node. The phosphate solution was applied at the arrow. Dotted curve and filled circles show the threshold values in normal Ringer's node and a solid curve shows those in test solution. Empty circles indicate the resting potential value. Room temperature $10^{\circ} \mathrm{C}$.

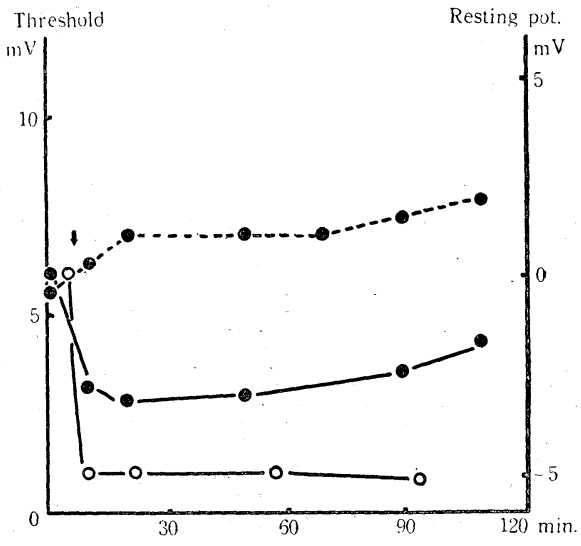

b) Threshold and spike form. Figure 2, $B$ shows the values of the thresholds of the nerve fiber obtained in a series of measurements. The threshold decreased to a certain minimum value (about $60 \%$ of the initial value) within a few minutes after the replacement of the solution, and was maintained at this value for the succeeding 20-30 minutes. Thereafter, the threshold began to rise gradually.

On the other hand the threshold of the normal node in another Ringer's pool was constant or increased simply with time. 
About 30 minutes after the application of the test solution, the magnitude of the action current leading from the node was found to be markedly decreased (fig. 3) and 50-60 minutes later, a spontaneous discharge was observed in a few cases.

$A$

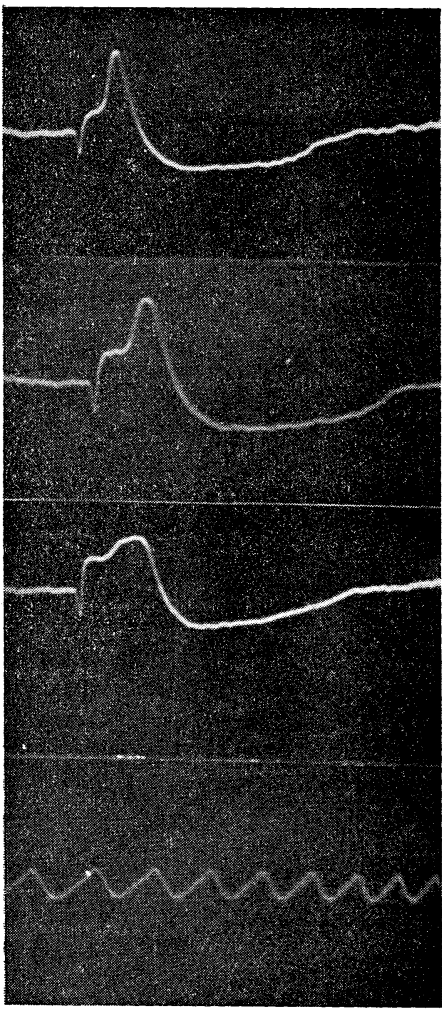

FIG. 3 (left). Effect of inorganic phosphate-Ringer's solution upon the configuration of the action current of a nerve fiber.

$A$ : normal binodal action current.

$B$ : action current of Ranvier's node ; 30 minutes after introduction of the inorganic phosphate-Ringer's solution into the central pool.

$C: 60$ minutes later. Time marker 550 cycles per second. The magnitude of the action current became small. $9.5^{\circ} \mathrm{C}$.
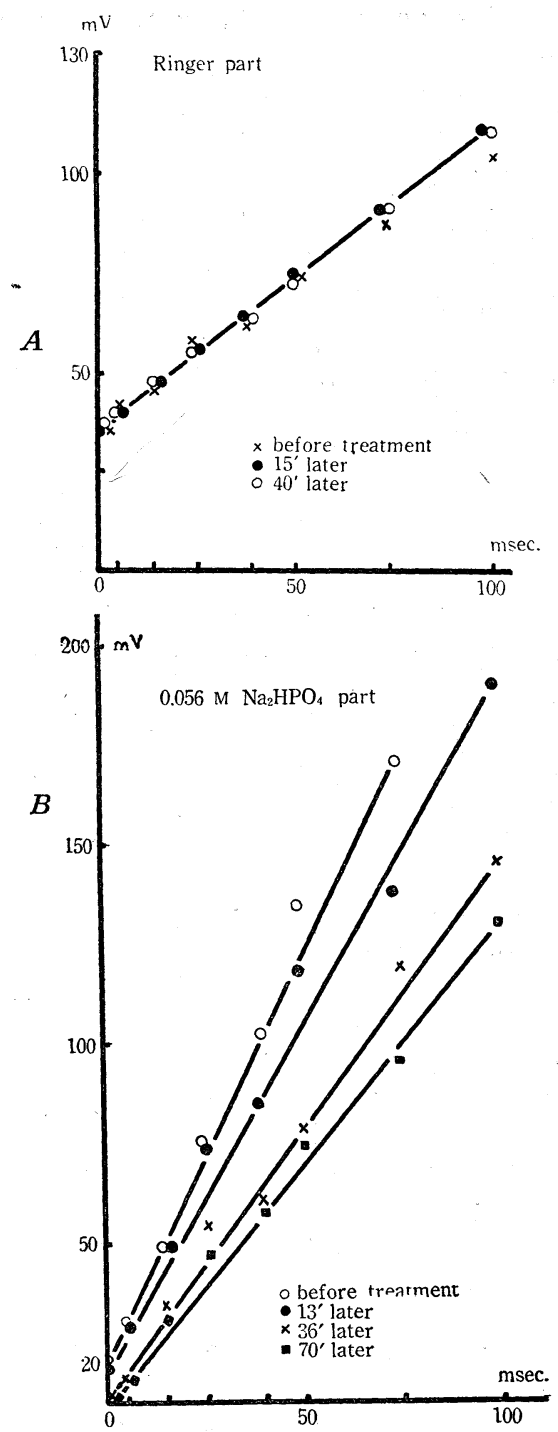

FIG. 4 (right). Effect of inorganic phosphate-Ringer's solution upon the accommodation curves. The final voltage of the just threshold was plotted as ordinate against the time constant of the voltage rise as abscissa. Curve in $(A)$ : an example of the accommodation curves of the normal node. Curves in $(B)$ : the accmmodation curves of the node treated with the test solution. The successive decrease of the rheobase and the minimal current gradient ( $\lambda$ value increase) after the application of inorgainc phosphate-Ringer's solution are shown. $12^{\circ} \mathrm{C}$. 
The ratio of change between the threshold and the resting potential, which was almost constant, was $\Delta$ threshold $/ \Delta$ resting potential $=0.45 \sim 0.57$.

c) Accommodation curve. After the Ringer's solution in the central pool was replaced by the inorganic phosphate solution, the accommodation curve decreased its inclination until, about 3 minutes later, the rheobase was found to be half the original value and the minimal current gradient also decreased to about two-thirds. On the other hand there was no change in the minimal gradient in the normal part. These results are presented in figure $4, A$ and $B$.

d) E-state. A result of the measurements of the E-state is given in table 1: $S_{0}$ is the threshold determined by a test condenser shock without a conditioning voltage; $S$ is the threshold of the test shock applied before or after the subliminal conditioning voltage; $V_{0}$ is the rheobase; and $V$ is the intensity of conditioning voltage, which was about $40 \%$ of the rheobase.

In figure 5 are presented one of the results of the extensive series. The curve in $(A)$ obtained in the normal node in the Ringer's solution shows that

TABLE 1. Effect of $0.056 \mathrm{M} \mathrm{Na}_{2} \mathrm{HPO}_{4}$-Ringer's Solution on the Excitatory State.

$S_{0}$ is the threshold determined by a test shock. $S$ is the value of the test shock which is applied before or after the subliminal conditioning voltage. $V_{0}$ is the rheobase. $V$ is the intensity of conditioning voltage, which is about $40 \%$ of the rheobase. $d$ is the distance between test shock and conditioning voltage ( $1 d$ is $0.7 \mathrm{msec}$.$) .$

\begin{tabular}{|c|c|c|c|c|c|c|c|c|c|c|c|c|c|}
\hline \multicolumn{7}{|c|}{ Part I $0.056 \mathrm{M} \mathrm{Na} \mathrm{HPO}_{4}$-Ringer solution } & \multicolumn{7}{|c|}{ Part II Ringer solution } \\
\hline $\begin{array}{c}\text { Time } \\
\text { after } \\
\text { soaking }\end{array}$ & $d$ & $\begin{array}{c}S \\
(\mathrm{mV})\end{array}$ & $\begin{array}{c}S_{0} \\
(\mathrm{mV})\end{array}$ & $\begin{array}{c}V \\
(\mathrm{mV})\end{array}$ & $\begin{array}{c}V_{0} \\
(\mathrm{mV})\end{array}$ & $S / S_{0}$ & $\begin{array}{c}\text { Time } \\
\text { after } \\
\text { soaking }\end{array}$ & $d$ & $\begin{array}{c}S \\
(\mathrm{mV})\end{array}$ & $\begin{array}{c}S_{0} \\
(\mathrm{mV})\end{array}$ & $\begin{array}{c}V \\
(\mathrm{mV})\end{array}$ & $\left|\begin{array}{c}V_{0} \\
(\mathrm{mV})\end{array}\right|$ & $S / S_{0}$ \\
\hline $0^{\prime}$ & $\begin{array}{l}1 \\
2 \\
2.5 \\
3 \\
3.5 \\
4 \\
4.5 \\
5 \\
5.5 \\
6 \\
6.5\end{array}$ & $\begin{array}{r}110 \\
110 \\
110 \\
92 \\
92 \\
86 \\
86 \\
93 \\
86 \\
96 \\
86\end{array}$ & $\begin{array}{l}117 \\
117 \\
117\end{array}$ & 3.52 & 8.8 & $\begin{array}{l}1.0 \\
1.0 \\
1.0 \\
0.84 \\
0.84 \\
0.73 \\
0.73 \\
0.79 \\
0.73 \\
0.79 \\
0.73\end{array}$ & $0^{\prime}$ & $\begin{array}{l}1 \\
2 \\
2.5 \\
3 \\
3.5 \\
4 \\
4.5 \\
5 \\
5.5 \\
6 \\
6.5\end{array}$ & $\begin{array}{l}510 \\
510 \\
510 \\
487 \\
460 \\
440 \\
440 \\
440 \\
440 \\
440 \\
440\end{array}$ & $\begin{array}{l}530 \\
530\end{array}$ & 8.1 & 20 & $\begin{array}{l}0.96 \\
0.96 \\
0.96 \\
0.92 \\
0.87 \\
0.83 \\
0.83 \\
0.83 \\
0.83 \\
0.83 \\
0.83\end{array}$ \\
\hline $15^{\prime}$ & $\begin{array}{l}1 \\
2.5 \\
3 \\
3.5 \\
4 \\
4.5 \\
5 \\
5.5 \\
6\end{array}$ & $\begin{array}{l}67 \\
62 \\
62 \\
57 \\
38.6 \\
43.5 \\
48.5 \\
46 \\
42.3\end{array}$ & $\begin{array}{l}57 \\
62 \\
\\
67\end{array}$ & 1.5 & 3.67 & $\begin{array}{l}1.08 \\
1.0 \\
0.92 \\
0.58 \\
0.65 \\
0.65 \\
0.72 \\
0.69 \\
0.63\end{array}$ & $20^{\prime}$ & $\begin{array}{l}1 \\
2.5 \\
3 \\
3.5 \\
4 \\
4.5 \\
5 \\
5.5 \\
6\end{array}$ & $\begin{array}{l}553 \\
553 \\
530 \\
487 \\
487 \\
487 \\
487 \\
465 \\
465\end{array}$ & 553 & 9 & 22.3 & $\begin{array}{l}1.0 \\
1.0 \\
0.96 \\
0.88 \\
0.88 \\
0.88 \\
0.88 \\
0.84 \\
0.84\end{array}$ \\
\hline $30^{\prime}$ & $\begin{array}{l}1 \\
2.5 \\
3 \\
3.5 \\
4 \\
4.5 \\
5 \\
6\end{array}$ & $\begin{array}{l}67 \\
62 \\
46 \\
38 \\
46 \\
42 \\
43 \\
42\end{array}$ & $\begin{array}{l}62 \\
62 \\
62\end{array}$ & 1.54 & 3.79 & $\begin{array}{l}1.06 \\
0.98 \\
0.73 \\
0.62 \\
0.74 \\
0.68 \\
0.70 \\
0.68\end{array}$ & $60^{\prime}$ & $\begin{array}{l}1 \\
2.5 \\
3 \\
3.5 \\
4 \\
4.5 \\
5 \\
5.5\end{array}$ & $\begin{array}{l}600 \\
600 \\
553 \\
530 \\
530 \\
530 \\
530 \\
530\end{array}$ & $\begin{array}{r}510 \\
510 \\
510\end{array}$ & 9.15 & 22.8 & $\begin{array}{l}1.0 \\
1.0 \\
092 \\
0.88 \\
0.88 \\
0.88 \\
0.88 \\
0.88\end{array}$ \\
\hline
\end{tabular}


TABLE 1. (Continued)

\begin{tabular}{|c|c|c|c|c|c|c|c|c|c|c|c|c|c|}
\hline \multicolumn{7}{|c|}{ Part I $0.056 \mathrm{M} \mathrm{Na}_{2} \mathrm{HPO}_{4}$-Ringer solution } & \multicolumn{7}{|c|}{ Part II Ringer solution } \\
\hline $\begin{array}{c}\text { Time } \\
\text { after } \\
\text { soaking }\end{array}$ & $d$ & $\begin{array}{c}S \\
(\mathrm{mV})\end{array}$ & $\begin{array}{c}S_{0} \\
(\mathrm{mV})\end{array}$ & $\begin{array}{c}V \\
(\mathrm{mV}) \\
\end{array}$ & $\begin{array}{c}V_{0} \\
(\mathrm{mV})\end{array}$ & $\mathrm{S} / S_{0}$ & \begin{tabular}{|c|} 
Time \\
after \\
soaking
\end{tabular} & $d$ & $\begin{array}{c}S \\
(\mathrm{mV}) \\
\end{array}$ & $\begin{array}{c}S_{0} \\
(\mathrm{mV})\end{array}$ & $\begin{array}{c}V \\
(\mathrm{mV})\end{array}$ & $\begin{array}{c}V_{0} \\
(\mathrm{mV}) \\
\end{array}$ & $S / S_{0}$ \\
\hline $45^{\prime}$ & $\begin{array}{l}1 \\
2 \\
2.5 \\
3 \\
3.5 \\
4 \\
4.5 \\
5 \\
5.5\end{array}$ & $\begin{array}{l}62 \\
62 \\
52 \\
52 \\
42 \\
46 \\
42 \\
46 \\
46\end{array}$ & $\begin{array}{l}64.5 \\
64.5 \\
64.5\end{array}$ & 1.34 & 3.3 & $\begin{array}{l}0.98 \\
0.98 \\
0.98 \\
0.81 \\
0.66 \\
0.71 \\
0.66 \\
0.71 \\
0.71\end{array}$ & $85^{\prime}$ & $\begin{array}{l}1 \\
2 \\
2.5 \\
3 \\
3.5 \\
4 \\
4.5 \\
5 \\
5.5\end{array}$ & $\begin{array}{l}630 \\
630 \\
630 \\
545 \\
545 \\
545 \\
545 \\
545 \\
545\end{array}$ & $\begin{array}{l}630 \\
630 \\
630\end{array}$ & 9.5 & $\begin{array}{l}23.1 \\
\\
23.1\end{array}$ & $\begin{array}{l}1.0 \\
1.0 \\
1.0 \\
0.87 \\
0.87 \\
0.87 \\
0.87 \\
0.87 \\
0.87\end{array}$ \\
\hline $70^{\prime}$ & $\begin{array}{l}1 \\
2 \\
2.5 \\
3 \\
3.5 \\
4 \\
4.5 \\
5 \\
5.5\end{array}$ & $\begin{array}{l}60 \\
60 \\
60 \\
55 \\
53 \\
53 \\
53 \\
53 \\
53\end{array}$ & $\begin{array}{l}51 \\
51 \\
51\end{array}$ & 9.15 & 22.8 & $\begin{array}{l}1.0 \\
1.0 \\
1.0 \\
0.92 \\
0.88 \\
0.88 \\
0.88 \\
0.88 \\
0.88\end{array}$ & & & & & & & \\
\hline
\end{tabular}
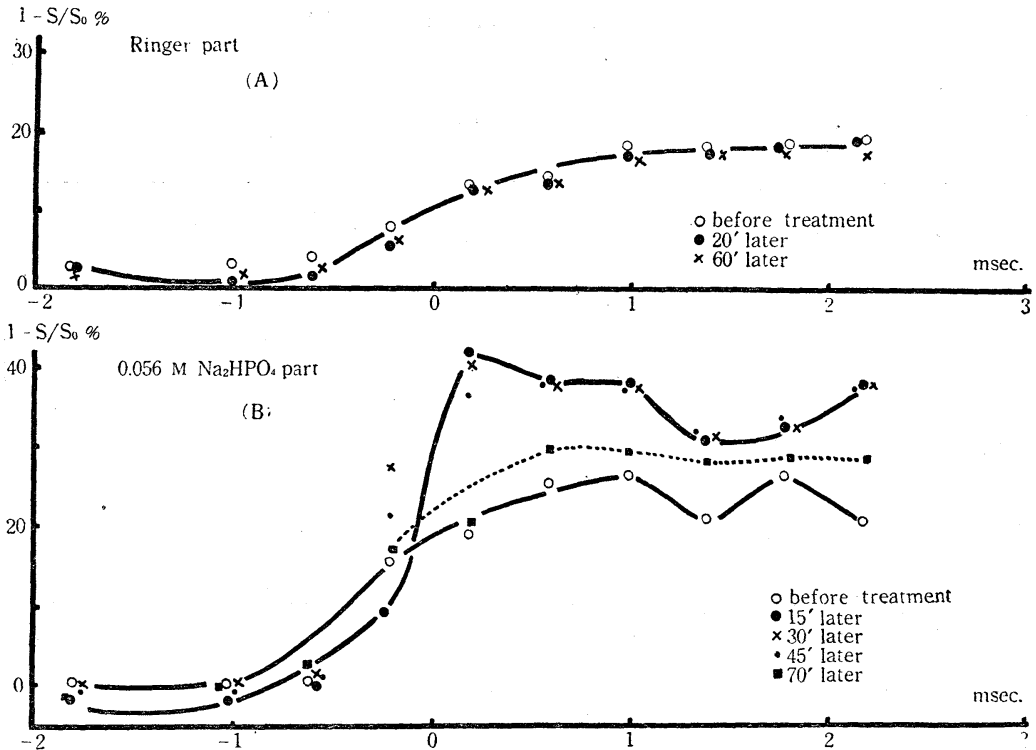

FIG. 5. Effect of inorganic phosphate-Ringer's solution upon the excitatory state. Curve in $(A)$ : an example of the excitatory state curves of the node in Ringer's part. The excitatory state is kept constant. Curves in $(B)$ : an example of the excitatory state curves in the test solution. 15 minutes leter this state is increased by $20 \%$ of the initial value. Ordinates : $S$ is the value of the test shock which is applied before or after a conditioning subliminal voltage. $S_{0}$ is the threshold determined by the test shock. Abscissae: the time between the conditioning voltage and test shock. (Negative sign shows that the test shock is applied before a conditioning voltage.) $9.5^{\circ} \mathrm{C}$. 
the E-state is kept constant during the course of this experiment. The curves in $(B)$ obtained at the node treated with the test solution, undoubtedly showed that the E-state was increased about $20 \%$, its maximum state was maintained for 40-50 minutes, and the original state recovered gradually.

One millisecond after applying the conditioning voltage, the regular fluctuation of $S$ value appeared occasionally, as is shown in figure 5 .

e) Effect of Ca-lack Ringer's solution. The threshold at the node to which the test solution was applied, was lowered by $20 \%$ within a few minutes. The effect of Ca-lack Ringer's solution was smaller than that of phosphate.

f) Oxygen uptake of phosphate-Ringer's solution and the Ca-lack Ringer's solution. The oxygen uptake, measured by Warburg's manometric method, was increased by application of phosphate and Ca-lack Ringer's solution, as shown in table 2.

TABLE 2. The Oxygen Consumption of Sciatic Nerves of Toads under Various Conditions

A : $0.056 \mathrm{M} \mathrm{Na}_{2} \mathrm{HPO}_{4}$-Ringer's solution. B : Ca-lack Ringer's solution.

Time interval shows succeeding 5 minutes.

(A) $21^{\circ} \mathrm{C}$.

\begin{tabular}{|c|c|c|c|c|c|c|c|c|c|c|c|c|c|}
\hline \multicolumn{2}{|c|}{ Minutes } & & 5 & 15 & 30 & 45 & $60^{\circ}$ & 75 & 90 & 105 & 120 & Total & Mean \\
\hline $\begin{array}{l}0.056 \mathrm{M} \\
\mathrm{Na}_{2} \mathrm{HPO}_{4} \\
\text { Ringer }\end{array}$ & $\begin{array}{l}\mathrm{O}_{2} \mathrm{cc} / \mathrm{g} . \\
\text { Fresh nerve }\end{array}$ & II & 36.5 & 41.5 & $\mid \begin{array}{l}38.4 \\
23.8\end{array}$ & 23.4 & $\begin{array}{l}42.4 \\
18.1\end{array}$ & 17.3 & $\begin{array}{l}31.6 \\
19.7\end{array}$ & & 31.9 & $\begin{array}{l}180.8 \\
143.8\end{array}$ & 162.3 \\
\hline Ringer & $\begin{array}{l}\mathrm{O}_{2} \mathrm{cc} / \mathrm{g} . \\
\text { Fresh nerve }\end{array}$ & II & | $33.3 \mid$ & 35.0 & $\left|\begin{array}{l}33.5 \\
19.8\end{array}\right|$ & 18.7 & $\left|\begin{array}{l}31.2 \\
12.4\end{array}\right|$ & 10.8 & $\begin{array}{l}16.9 \\
10.5\end{array}$ & & 19.9 & $\begin{array}{l}134.8 \\
107.2\end{array}$ & 121.0 \\
\hline
\end{tabular}

(B) $20^{\circ} \mathrm{C}$.

\begin{tabular}{|c|c|c|c|c|c|c|c|c|c|c|c|c|c|}
\hline \multicolumn{2}{|c|}{ Minutes } & & 5 & 15 & 30 & 45 & 60 & 75 & 90 & 105 & 120 & Total & Mean \\
\hline $\begin{array}{l}\text { Ca-lack } \\
\text { Ringer }\end{array}$ & $\begin{array}{l}\mathrm{O}_{2} \mathrm{cc} / \mathrm{g} . \\
\text { Fresh nerve }\end{array}$ & \begin{tabular}{|c|} 
I \\
II \\
III \\
IV
\end{tabular} & $\begin{array}{l}18.5 \\
16.3 \\
11.9\end{array}$ & \begin{tabular}{|}
34.6 \\
16.0 \\
16.3 \\
11.9
\end{tabular} \mid & $\begin{array}{r}17.3 \\
9.0 \\
16.3 \\
16.2 \\
\end{array}$ & $\left|\begin{array}{l}23.3 \\
21.0 \\
20.4 \\
12.3\end{array}\right|$ & \begin{tabular}{|r|}
6.4 \\
24.0 \\
13.0 \\
16.6 \\
\end{tabular} & $\mid \begin{array}{r}16.8 \\
17.5 \\
8.5 \\
9.0 \\
\end{array}$ & $\begin{array}{r}11.2 \\
16.0 \\
14.3 \\
8.6\end{array}$ & $\begin{array}{l}13.8 \\
19.0 \\
16.7 \\
11.9\end{array}$ & $\begin{array}{r}20.7 \\
11.0 \\
12.2 \\
7.5\end{array}$ & $\begin{array}{r}144.1 \\
133.5 \\
117.7 \\
94.0 \\
\end{array}$ & 122.3 \\
\hline Ringer & $\begin{array}{l}\mathrm{O}_{2} \mathrm{cc} / \mathrm{g} . \\
\text { Fresh nerve }\end{array}$ & \begin{tabular}{|l|} 
I \\
II \\
III \\
IV
\end{tabular} & $\begin{array}{c}11.0 \\
0.95 \\
5.7\end{array}$ & $\left|\begin{array}{r}30.0 \\
17.1 \\
8.5 \\
9.1\end{array}\right|$ & $\begin{array}{c}15.0 \\
4.59 \\
9.5 \\
10.7\end{array}$ & $\left|\begin{array}{l}20.1 \\
21.6 \\
19.9 \\
10.2\end{array}\right|$ & $\begin{array}{r}4.0 \\
22.9 \\
16.1 \\
9.8\end{array}$ & \begin{tabular}{|r|}
15.9 \\
17.2 \\
9.5 \\
7.2
\end{tabular} & $\begin{array}{r}9.0 \\
12.0 \\
17.4 \\
6.6\end{array}$ & $\begin{array}{r}11.2 \\
17.8 \\
12.3 \\
7.4\end{array}$ & $\begin{array}{r}16.3 \\
11.0 \\
11.8 \\
6.5\end{array}$ & $\begin{array}{r}121.5 \\
119.2 \\
105.0 \\
67.5\end{array}$ & 104.4 \\
\hline
\end{tabular}

\section{Effect of Organic Phosphate Compounds}

A) Effect of 0.005-0.01 м CrP

a) Resting potential. No effect upon the resting potential was observed for scores of minutes after the establishment of the contact with the test solution.

It has been shown in many experiments that the effect of $\operatorname{CrP}$ is greatly increased by $\mathrm{Mg}$ ions or $\mathrm{Zn}$ ions which are largely responsible for many catalytic actions on the CrP. For verification of this fact, it is sufficient to make experiments with $\mathrm{CrP}$ with $\mathrm{Mg}$ ions. However, in our experiment there was ob- 
served no further change in the resting potential by $\operatorname{CrP}$ with $0.01 \mathrm{M} \mathrm{MgCl}_{2}$ than by $\mathrm{CrP}$ alone.

b) Threshold. The threshold was temporarily increased by about $15 \%$ after introduction of the CrP-solution. However, after a short time it was raised continuously in parallel to the rise of the threshold of the node in the Ringer's solution.

On the whole, the effect of $\mathrm{CrP}$ with $0.01 \mathrm{M} \mathrm{MgCl}_{2}$ showed some difference from that with $\mathrm{CrP}$ without $\mathrm{MgCl}_{2}$, the threshold increasing more slowly than that in Ringer's part and the threshold had the tendency to be maintained at a constant. The form and duration of the action potential remained normal.

c) E-state. There were small changes in the E-state in the part of $\mathrm{CrP}$; for examples, there appeared no change in two cases, an increase by $5 \%$ in a third and a decrease by $10 \%$ in a fourth. As compared with the effect of $\mathrm{CrP}$ alone, the E-state increased remarkably (by about $15 \%$ of the initial value) 10 minutes after the application of the $\mathrm{CrP}$ with $0.01 \mathrm{M} \mathrm{MgCl}_{2}$, and this increased state was maintained for 30-40 minutes and returned to the initial state 70-100 minutes later (fig. $6, A$ and $B$ ).

It seems highly important that the E-state is influenced by $\mathrm{Mg}$ ions although $\mathrm{CrP}$ alone has no effect. It has been so far considered that $\mathrm{Mg}$ ions acted as a catalytic agent upon the effect of energy-rich phosphate compounds, as has been
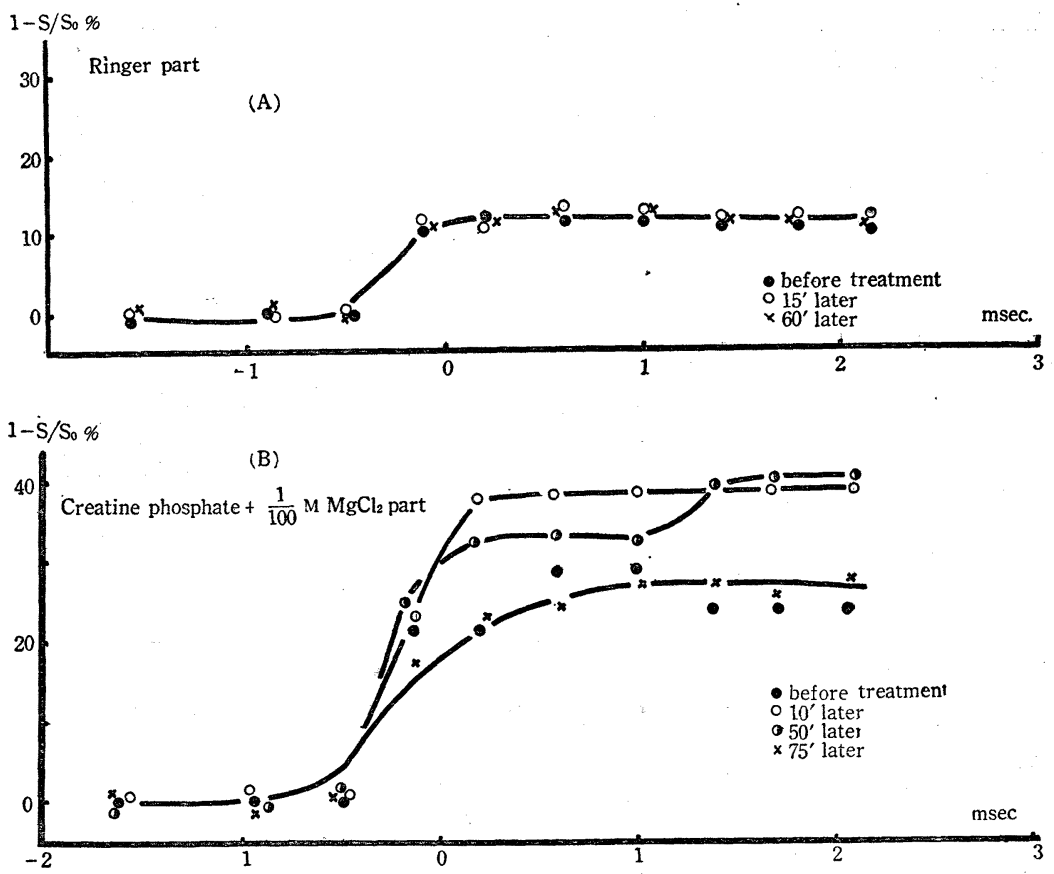

FIG. 6. Effect of $0.01 \mathrm{M} \mathrm{CrP}$ with $0.01 \mathrm{M} \mathrm{Mg}$ ions upon the excitatory state. Curve in $(A)$ : an example of the excitatory state curves of the node in Ringer's part. Curves in $(B)$ : an example of the excitatory state curves in the test solution. This state increased by $15 \%$ of its initial value 10 minutes after the application of test solution. $12^{\circ} \mathrm{C}$. 
shown in the muscle contraction or in enzyme action specifically. The essential point seems to be to decide if the remarkable findings mentioned above, are due to the effect of $\mathrm{Mg}$ ions alone or the summated action of the $\mathrm{CrP}$ and $\mathrm{Mg}$ ions on the E-state.

However, the E-state of the part immersed in Ringer's solution with 0.01 $\mathrm{M} \mathrm{MgCl}_{2}$ was always found to be constant. Therefore, this increase of the E-state might be accounted for by the effect of $\mathrm{Mg}$ ions upon the $\mathrm{CrP}$.

B) Effect of $0.3 \times 10^{-3} \sim 2 \times 10^{-3} \mathrm{M}$ ATP

a) Resting potential and threshold. At $0.3 \times 10^{-3}$ to $2 \times 10^{-3} \mathrm{M}$ ATP the threshold was lowered to $40-50 \%$ of the initial value (fig. 7 ).

The resting potential of the node immersed in the test solution became positive (outflowing current from its inner side) with the change of the threshold.

As the $20 \%$ fall of the threshold at the normal node in Ringer's solution cannot be explained by the electrotonus, it seems that ATP molecules were diffused to the contrasted node. The addition of $0.01 \mathrm{M} \mathrm{ZnCl}_{2}, 0.01 \mathrm{M}$ $\mathrm{MgCl}_{2}$ and $0.01 \mathrm{M} \mathrm{KCl}$ to the ATP solution increased the threshold.

b) E-state. The E-state was in-

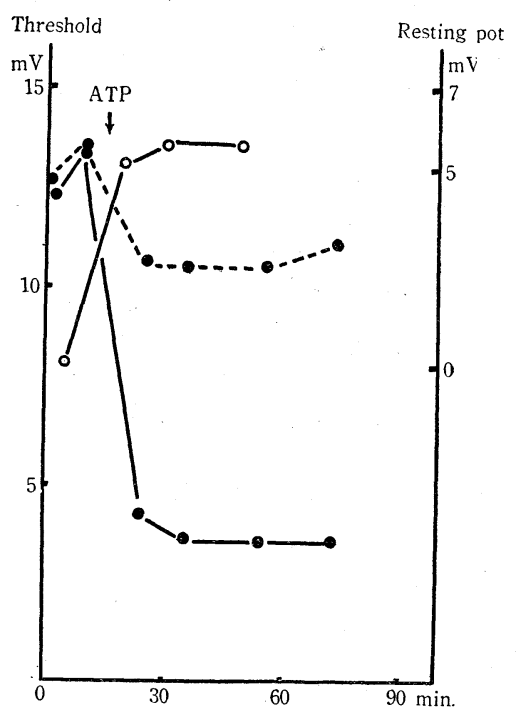

FIG. 7. A series of measurements of the resting potential and the threshold changes resulting from $0.00083 \mathrm{M}$ ATP. The threshold at normal Ringer's node lowered also. The mark indicates the moment of application of ATP solution. $12^{\circ} \mathrm{C}$. creased by $15 \%$ in $0.3 \times 10^{-3} \sim 2 \times 10^{-3} \mathrm{M}$ ATP compared with the normal value, but the further addition of $\mathrm{Mg}$ ions $(0.01 \mathrm{M})$ did not show a further increase in the E-state.

c) Oxygen consumption. As shown in table 3, the oxygen uptake of nerve fibers was slightly increased in $10^{-3} \mathrm{M}$ ATP concentration.

TABLE 3. The Oxygen Consumption of Sciatic Nerves of Toads after the Application of ATP $\left(21^{\circ}\right.$ C.)

\begin{tabular}{|c|c|c|c|c|c|c|c|c|c|c|c|c|c|c|c|c|}
\hline \multicolumn{3}{|c|}{ Minutes } & 5 & 10 & 15 & 20 & 25 & 30 & 35 & 40 & 45 & 50 & 55 & 60 & Total & Mean \\
\hline $\begin{array}{l}0.0007 \mathrm{M} \\
\text { ATP-Ringer }\end{array}$ & $\begin{array}{r}\mathrm{O}_{2} \mathrm{cc} / \mathrm{g} . \\
\text { Fresh } \\
\text { nerve }\end{array}$ & II & $\begin{array}{l}4.51 \\
5.0\end{array}$ & $\left|\begin{array}{l}3.01 \\
3.2\end{array}\right|$ & $\begin{array}{l}3.3 \\
3.6\end{array}$ & $\begin{array}{l}4.27 \\
4.8\end{array}$ & $\begin{array}{l}4.99 \\
3.5\end{array}$ & $\begin{array}{l}3.1 \\
3.5\end{array}$ & $\begin{array}{l}3.8 \\
3.8\end{array}$ & $\begin{array}{l}1.6 \\
2.3\end{array}$ & $\begin{array}{l}2.6 \\
3.0\end{array}$ & $\begin{array}{l}4.3 \\
4.8\end{array}$ & $\begin{array}{l}0.7 \\
1.2\end{array}$ & $\begin{array}{l}4.0 \\
4.0\end{array}$ & $\begin{array}{l}40.18 \\
42.7\end{array}$ & 41.44 \\
\hline Ringer & $\begin{array}{c}\mathrm{O}_{2} \text { ec/g. } \\
\text { Fresh } \\
\text { nerve }\end{array}$ & I & $\begin{array}{l}2.3 \\
3.0\end{array}$ & $\begin{array}{l}4.9 \\
3.3\end{array}$ & $\begin{array}{l}3.8 \\
3.1\end{array}$ & $\begin{array}{l}4.6 \\
4.0\end{array}$ & $\begin{array}{l}3.58 \\
3.7\end{array}$ & $\begin{array}{l}1.5 \\
2.5\end{array}$ & $\begin{array}{l}3.1 \\
3.1\end{array}$ & $\begin{array}{l}1.8 \\
2.5\end{array}$ & $\begin{array}{l}3.1 \\
2.3\end{array}$ & $\begin{array}{l}4.3 \\
4.5\end{array}$ & $\begin{array}{l}0.5 \\
0.8\end{array}$ & $\begin{array}{l}2.3 \\
3.5\end{array}$ & $\begin{array}{l}35.7 \\
37.3\end{array}$ & 36.5 \\
\hline
\end{tabular}

DISCUSSION

According to recent information the energy-rich phosphate compounds in 
the living tissues play an important rôle in muscle contraction, secretion and adsorption. If so, the same mechanism may readily be accountable in considering too nervous activities (Advances in enzymology IV, Höber, '47). Nachmansohn ("29) found that there was a parallelism between the chronaxie of muscle and the contents of CrP. Boyarsky et al. ('49) observed that methylfluoracetate decreased the $Q_{\mathrm{O}_{2}}$ value of the nerve and acted on the form of the action current, threshold and conduction velocity. These effects were reported to be depressed by succinate or fumarate. These evidences have established the fact that the nervous activity is chiefly referable to aerobic metabolism from pyruvate to $\mathrm{H}_{2} \mathrm{O}$ and $\mathrm{CO}_{2}$ (Some investigators accepted the same opinion) (Shanes, '42, '44, '46, Lorente de Nó, '47, Crane, '50). The authors found that pyruvate effected the threshold, the resting potential and the oxygen consumption of nerve (in preparation).

As shown in our experiments, inorganic phosphate ions effected the threshold, and oxygen uptake. Therefore, it seems that the lowering of the threshold in this case is associated with the increased oxygen consumption. On the other hand, Bonnet and Monnier ("47) observed the facilitated effect of inorganic phosphate ions upon frog spinal cord and concluded from this that the decalcification resulting from the production of $\mathrm{CaHPO}_{4}$ might have influenced its activity. In fact, Ringer's solution without $\mathrm{Ca}$ affects the threshold as well as oxygen uptake, as phosphate ions do.

Hence, it follows that this result was due either by decalcification or by the presence of potassium ions, the effect of which was made clear by disappearance of antagonistic $\mathrm{Ca}$ ions. In either case, it is clear that the threshold is related to oxygen consumption.

When next we consider the case of $\mathrm{CrP}$, as was shown in our experiment, it is interesting that $\mathrm{CrP}$ alone failed to retard the rise of the threshold, but, by the addition of $\mathrm{Mg}$ ions to the $\mathrm{CrP}$ solution the E-state was increaed by $15 \%$ when compared with the normal value, without any rise in the threshold, which was $\Delta S / \Delta S_{0}>1$. Next, it was shown that the excitability enhanced by subliminal stimulation, was greater in $\mathrm{CrP}+\mathrm{Mg}$ ions than in Ringer's solution. It seems that this fact is due to the following mechanism.

In the nerve, it is conceivable that Lohmann's equilibrium exists between ATP and CrP, and that the excitability is increased in consequence to the production of ATP by the decomposition of $\mathrm{CrP}$ when the nerve is stimulated subliminally. However, in this reaction $\mathrm{Mg}$ ions are involved too, as follows:

$$
\mathrm{CrP}+\mathrm{ADP} \stackrel{\mathrm{Mg}^{++}}{\rightleftarrows} \mathrm{Cr}+\mathrm{ATP}
$$

$\mathrm{In}^{5}$ the presence of both $\mathrm{CrP}$ and $\mathrm{Mg}$ ions, the above mentioned reaction may be accelerated to the right by subliminal stimulation, and the irritability of nerve may be enhanced as ATP increases.

Next, in a low concentration of ATP, the threshold was lowered, and the E-state increased and positive resting potential was produced at the node treated with ATP, but the oxygen consumption was not affected to a marked extent. The fact is obviously due to the presence of energy-rich phosphate bonds. How- 
ever, it cannot, by itself, be decided immediately whether the increased resting potential is directly related to the energy-rich phosphate bonds in the protoplasm or due to the increase in potassium ions caused by these bonds. Moreover, one of the present author observed that these energy-rich phosphate compounds are related to potassium accumulation in nerve fiber (in preparation).

The above described observations lead to the conclusion that the oxidative metabolism and the energy-rich phosphate compounds produced by oxidative pyruvate metabolism, may play a very important rôle in nerve activity.

\section{SUMMARY}

Measurements of the resting potential, the threshold, the accommodation curve and the excitatory state were made in the hope that some information might be gained as to the relation between nervous activity and phosphate metabolism, especially to the mechanism of action of an inorganic phosphate, organic phosphate compounds viz., $\mathrm{CrP}$ or $\mathrm{ATP}$, and $\mathrm{Mg}$ ions in the active as well as the resting state of a nerve fiber.

1. The effect of the inorganic phosphate on the nervous activity. Ranvier's node treated with inorganic phosphate, $0.056 \mathrm{M} \mathrm{Na}_{2} \mathrm{HPO}_{4}$-Ringer's solution ( $p \mathrm{H}$ $7.6, \Delta=0.45^{\circ} \mathrm{C}$.), was affected by the inflowing current from its outer side (membrane potential decreased at this node). The threshold was lowered to about $60 \%$ of the initial value for some $20-30$ minutes after application of the test solution and brought back to the initial value after 60 minutes.

The minimal current gradient decreased ( $\lambda$ value increased). The excitatory state was elevated by about $20 \%$ from the initial value. Moreover oxygen consumption was enhanced by it.

2. $\mathrm{CrP}$ had no influence on nervous activity, but the addition of $\mathrm{Mg}$ ions raised the excitatory state by $15 \%$ of its initial value.

3. ATP affects nervous activity, viz. the threshold is lowered by $50 \%$, the E-state elevated by $15 \%$ and the resting potential increased at the node applied with ATP (the outflowing current from its inner side).

The present experiments indicated that nervous activity is intimately related to the oxidative metabolism and the energy-rich phosphate bonds.

Our sincere thanks are due to Prof. Naoki Toida for his very helpful advices and criticism; to Dr. Masayasu Sato for his continual advice, and to Mr. Hiroshi Ooyama for the device of the stimulating apparatus used in our study.

\section{REFERENCES}

1. Potter, V.R. Biological Energy Transformations and the Cancer Probrem, in $A d v$. in Enzymol. 4 : 201, New York: Interscience Publishers, 1944.

2. Boyarsky, L. L., Rosenblatt, A. D. Postel, S. And Gerard, R. W. Am. J. Physiol. $157: 291,1949$.

3. Bonnet, V. et Monnier, A. M. Arch. intern. Physiol. 55 : 27, 1947.

4. CRANE, E. E. Progress in Biophysics and Biophysical Chemistry, I: 85, London: Butterworth-Springer, 1950

5. Embden, G. AND ZimmermanN, M. Z. physiol. Chem. 167: 137, 1927. 
6. Eggleton, P. And Eggleton, G. P. Biochem. J. 21: 190, 1927.

7. Fiske, C. H. AND Subbarow, Y. J. Biol. Chem. 81: 629, 1929.

8. Hill, A. V. Proc. Roy. Soc. B, 119: 305, 1936.

9. HÖBER, R. Physical Chemistry of Cells and Tissues. 437, Philadelphia, Toronto: Blakiston Comp., 1947.

10. KERR, S. E. J. Biol. Chem. 149 : 121, 1941.

11. LIPMANN, F. Metabolic Process Patterns, in Currents in Biochemical Research, 137, New York: Interscience, 1946.

12. LORENTE DE Nó, R. A Study of Nerve Physiol. Part I, New York: Rockefeller Institute for Medical Research, 1947.

13. MINZ, B. La transmission chimique de l'influx nerveux, Paris : 1947.

Flammarion, F. HaUROwitz. Fortschritte der Biochemie, 318, Basel (Schweiz) : 1948.

14. NACHMANSOHN, D. Bioch. Zeit. $213: 262,1929$.

15. NACHMANSOHN, D. Chemical Mechanism of Nervous Action, in Currents in Biochemical Reserch, 335, New York: Interscience, 1946.

16. SATO, M. Jap. J. Physiol. 1: 309, 1951.

17. SATO, M. AND KogA, S. Kagaku 22: 150, 1952.

18. Shanes, A. M. J. cell and comp. Physiol. 19: 1 and 249, 1942.

19. SHANES, A. M. J. cell and comp. Physiol. 243: 157, 1944.

20. Shanes, A. M. Fed. Proc. 5: 93-94, 1946.

21. TASAKI, I. Am. J. Physiol. $125: 367,1939$.

22. TASAKI, I. Bioch. Biophys. Acta 3: 498, 1949.

23. TASaki, I. AND SAKAgUChI, M. Jap. J. Physiol. 1: 7, 1950. 